\title{
ESTIMASI CADANGAN KLAIM MENGGUNAKAN GENERALIZED LINEAR MODEL (GLM) DAN COPULA
}

\author{
Yuciana Wilandari ${ }^{1,2 *}$, Sri Haryatmi Kartiko $0^{3}$, Adhitya Ronnie Effendie ${ }^{3}$ \\ ${ }^{1}$ Departemen Statistika, Fakultas Sains dan Matematika, Universitas Diponegoro \\ ${ }^{2}$ Prodi S3 Matematika, Fakultas MIPA, Universitas Gadjah Mada \\ ${ }^{3}$ Departemen Matematika, Fakultas MIPA, Universitas Gadjah Mada \\ *yuciana.wilandari@gmail.com
}

\begin{abstract}
In the articles of this will be discussed regarding the estimated reserves of the claim using the Generalized Linear Model (GLM) and Copula. Copula is a pair function distribution marginal becomes a function of distribution of multivariate. The use of copula regression in this article is to produce estimated reserves of claims. Generalized Linear Model (GLM) used as a marginal model for several lines of business. In research it is used three kinds of line of business that is individual, corporate and professional. The copula used is the Archimedean type of copula, namely Clayton and Gumbel copula. The best copula selection method is done using A kaike Information Criteria (AIC). Maximum Likelihood Estimation (MLE) is used to estimate copula parameters. The copula model us ed is the Clay ton copula as the best copula. The parameter estimation results are used to obtain the estimated reserve value of the claim.
\end{abstract}

Keywords: Claim Reserve, Copula, Generalized Linear Model

\section{PENDAHULUAN}

Klaim asuransi merupakan proses pengajuan yang dilakukan oleh peserta asuransi untuk mendapatkan uang pertanggungan setelah peserta melaksanakan seluruh kewajibannya kepada perusahaan asuransi berupa penyelesaian pembayaran premi sesuai dengan kesepakatan yang telah dilakukan sebelumnya. Banyaknya klaim yang diajukan oleh peserta asuransi dapat dikatakan sebagai suatu bentuk risiko kerugian bagi perusahaan asuransi. Oleh karena itu, suatu perusahaan asuransi harus dapat mengelolanya dengan baik agar tidak mengalami kerugian/kebangkrutan. Pada beberapa jenis asuransi pembayaran klaim dapat dilakukan dalam satu kali pembayaran dengan jangka waktu yang tidak lama setelah klaim dilaporkan. Namun pada beberapa jenis asuransi yang lain, pembayaran klaim dilakukan lebih dari satu kali pembayaran serta membutuhkan waktu yang cukup lama untuk penyelesiannya terhitung sejak pengajuan klaim dilakukan. Dalam bidang asuransi hal ini dikenal dengan istilah long tailed business, dimana waktu penundaan antara terjadinya klaim sampai dengan penyelesaiannya terhitung lama mungkin lebih dari satu tahun, misalnya seperti asuransi tanggung gugat, asuransi malpraktik medis, asuransi pesawat terbang, dan reasuransi.

Akibat adanya rentang waktu saat pengajuan klaim sampai penyelesaian pembayaran klaim dalam long tailed business terjadilah hutang klaim. Untuk mengatasi hutang klaim suatu perusahaan asuransi harus memiliki dana khusus yang disiapkan untuk melunasi hutang klaim. Hal ini dikenal dengan istilah cadangan klaim (Mack, 1993). Estimasi cadangan klaim memegang peranan penting dalam suatu perusahaan asuransi, hal ini dikarenakan jika suatu perusahaan asuransi tidak dapat mengestimasi cadangan klaim dengan baik maka perusahaan dapat mengalami kebangkrutan.

Beberapa model telah dikembangkan untuk menentukan cadangan klaim, seperti dalam England dan Verral (2002) serta Wüthrich dan Merz (2008) cadangan klaim ditentukan dengan menggunakan metode klasik untuk single line of business. Sedangkan dalam penelitian Pevšta dan Okhrin (2014) dibahas tentang estimasi cadangan klaim untuk 
single line of business yang mengasumsikan adanya ketergantungan antar eror dari besar klaim karena berkembangnya waktu dalam satu tahun kejadian, dimana dependensinya dimodelkan dengan model Conditional Mean and Variance (CMV) dan copula. Namun, pada praktiknya hampir setiap perusahaan asuransi memiliki berbagai macam line of business. Dari sini dapat diasumsikan bahwa setiap line of business memiliki ketergantungan satu sama lain. Oleh karena itu untuk menentukan nilai cadangan dari keseluruhan line of business perlu diketahui dengan jelas hubungan antar line of business. Dalam penelitian Shi dan Frees (2011) ketergantungan antar line of business dapat dimodelkan dengan regresi copula. Sedangkan menurut Valentovičová (2015) dan Rahmah (2019) untuk menentukan cadangan klaim pada kasus dua line of business dapat dilakukan dengan memodelkan data klaim menggunakan Generalized Linear Model (GLM), dan ketergantungan antar line of business dapat diestimasi menggunakan copula. Sehingga tujuan dari penulisan artikel ini adalah menentukan estimasi cadangan klaim beberapa line of business menggunakan Generalized Linear Model (GLM) dan copula, dalam hal ini tiga line of business.

\section{TINJAUAN PUSTAKA}

\subsection{Generalized Linear Model (GLM)}

McCullagh dan Nelder (1989) menyatakan bahwa GLM merupakan perluasan dari model linear dimana variabel responnya tidak harus berdistribusi normal. Variabel respon biasanya mengikuti anggota distribusi keluarga eksponensial seperti Normal, Poisson, Binomial, Gamma, dan Inverse Gaussian. Dalam GLM mean dari variabel responnya berhubungan dengan kombinasi linear kovariat melalui fungsi penghubung (link function).

GLM memiliki 3 karakteristik utama, yaitu:

1. Asumsi distribusi, dengan variabel respon (variabel dependen) merupakan variabel random $Y_{1}, Y_{2}, \ldots, Y_{n}$ dengan $E\left[Y_{i}\right]=\mu_{i}$ diasumsikan mempunyai fungsi densitas dari keluarga eksponensial.

2. Komponen sistematik, prediktor linear menghubungkan dan memberi spesifikasi pengaruh variabel penjelas $\boldsymbol{X}_{i}$ ke mean dari variabel respon $Y_{i}$. Dengan $\eta_{i}$ merupakan kombinasi linear antara koefisien regresi $\boldsymbol{\beta}$ yang merupakan vektor parameter berukuran $p \times 1$, dan $\boldsymbol{X}_{i}$ yang merupakan vektor kovariat berukuran $p \times 1$, dapat ditulis :

$$
\begin{gathered}
\eta_{i}=\boldsymbol{x}_{i}^{T} \boldsymbol{\beta}=\beta_{0}+\beta_{1} x_{i 1}+\beta_{2} x_{i 2}+\cdots+\beta_{p} x_{i p} \\
\text { dengan } \boldsymbol{\beta}=\left(\beta_{0}, \beta_{1}, \beta_{2}, \ldots, \beta_{p}\right)^{T} \text { dan } \boldsymbol{x}_{\boldsymbol{i}}=\left(1, x_{i 1}, x_{i 2}, \ldots, x_{i p}\right)^{T}
\end{gathered}
$$

3. Fungsi penghubung (link function) adalah fungsi yang menghubungkan nilai $E\left(Y_{i}\right)=$ $\mu_{i}$ dengan $\eta_{i}$.

$$
g\left(\mu_{i}\right)=\boldsymbol{x}_{i}^{T} \boldsymbol{\beta}
$$

Oleh karena itu, bentuk GLM dari $Y_{i}$ dapat ditulis:

$$
g\left(\mu_{i}\right)=\eta_{i}=\beta_{0}+\beta_{1} x_{i 1}+\beta_{2} x_{i 2}+\cdots+\beta_{p} x_{i p}
$$

\subsection{Copula Archimedean}

Copula Archimedean merupakan jenis copula yang memiliki bentuk yang cukup sederhana, copula Archimedean seringkali digunakan dalam pengaplikasian teori keuangan, dan asuransi. Menurut Nelsen (2006) bentuk copula Archimedean adalah sebagai berikut:

$$
C(u, v)=\varphi^{-1}(\varphi(u)+\varphi(v))
$$


untuk $0 \leq u$ dan $v \leq 1$, dengan $\varphi$ merupakan pembangkit (generator) dari $C$ dengan $\varphi(0)=\infty$ dan $\varphi(1)=0$.

\section{a. Copula Clayton}

Copula Clayton pertama kali diperkenalkan oleh Clayton (1978). Fungsi pembangkit (generator) dari copula Clayton adalah $\varphi(u)=\frac{1}{\theta}\left(u^{-\theta}-1\right)$. Untuk kasus copula dua dimensi (bivariat), fungsi copula Clayton dapat ditulis sebagai berikut:

$$
C^{\text {Clay }}(u, v)=\left(u^{-\theta}+v^{-\theta}-1\right)^{-\frac{1}{\theta}}
$$

Dengan menderivatifkan Persamaan (5) terhadap $u$ dan $v$, maka diperoleh fungsi densitas copula Clayton sebagai berikut:

$$
{ }^{\operatorname{Clay}}(u, v)=\frac{(1+\theta)\left(u^{-\theta}+v^{-\theta}-1\right)^{-\left(\frac{1}{\theta}+2\right)}}{(u v)^{\theta+1}}
$$

\section{b. Copula Gumbel}

Copula Gumbel pertama kali diperkenalkan oleh Gumbel (1960). Fungsi pembangkit (generator) dari copula Gumbel adalah $\varphi(u)=(-\ln u)^{\theta}$. Untuk kasus copula dua dimensi (bivariat), fungsi copula Gumbel dapat ditulis sebagai berikut:

$$
C^{G u}(u, v)=\exp \left\{-\left[(-\ln u)^{\theta}+(-\ln v)^{\theta}\right]^{\frac{1}{\theta}}\right\}
$$

Dengan menderivatifkan Persamaan (7) terhadap $u$ dan $v$, maka diperoleh fungsi densitas copula Gumbel sebagai berikut:

$$
\begin{aligned}
c^{G u}(u, v)= & c^{G u}(u, v) u^{-1} v^{-1}(\ln u)^{\theta-1}(\ln v)^{\theta-1} \\
& {\left[(-\ln u)^{\theta}+(-\ln v)^{\theta}\right]^{-2+\frac{1}{\theta}}\left\{\left[(-\ln u)^{\theta}+(-\ln v)^{\theta}\right]^{\frac{1}{\theta}}+\theta-1\right\} }
\end{aligned}
$$

\subsection{Pemodelan Data Klaim}

Dinotasikan besar pembayaran klaim incremental sebagai $X_{i, j}^{(n)}$, dengan $i \in$ $\{1,2, \ldots, I\}$ dan $j \in\{1,2, \ldots, J\}, n$ dalam $X_{i, j}^{(n)}$ menunjukkan besar pembayaran klaim incremental pada line of business ke- $n$, dengan $n \in\{1,2, \ldots, N\}$. Diasumsikan bahwa $X_{i, j}^{(n)}$ merupakan besar pembayaran klaim incremental yang terstandarisasi, dapat ditulis sebagai berikut:

$$
X_{i, j}^{(n)}=\frac{\tilde{X}_{i, j}^{(n)}}{\omega_{i}^{(n)}}
$$

dengan $\tilde{X}_{i, j}^{(n)}$ merupakan besar pembayaran klaim incremental asli pada line of business ke$n$, dan $\omega_{i}^{(n)}$ merupakan variabel exposure pada periode kejadian ke- $i$ untuk line of business ke- $n$. Variabel exposure yang akan digunakan dalam penelitian ini adalah banyaknya polis. Diasumsikan bahwa $X_{i, j}^{(n)}$ memiliki fungsi distribusi $F_{i, j}^{(n)}$. Sesuai dengan Shi dan Frees (2011), maka fungsi distribusi $F_{i, j}^{(n)}$ dapat ditulis sebagai berikut:

$$
F_{i, j}^{(n)}=P\left\{X_{i, j}^{(n)} \leq x_{i, j}^{(n)}\right\}=F^{(n)}\left(\eta_{i, j}^{(n)} ; \gamma^{(n)}\right)
$$

dengan $n \in\{1,2, \ldots, N\}$ dan $\gamma^{(n)}$ merupakan parameter dispersi, sedangkan parameter $\eta_{i, j}^{(n)}$ merepresentasikan komponen sistematik dari distribusi.

Diasumsikan terdapat dua variabel prediktor yang bersifat independen yaitu periode kejadian dan periode perkembangan, dinotasikan dengan $\alpha_{i}^{(n)}, i \in\{1,2, \ldots, I\}$ dan $\delta_{j}^{(n)}, j \in$ $\{1,2, \ldots, J\}$. Maka dapat dibentuk komponen sistematik dari model GLM untuk line of business ke- $n$ pada segitiga run-off sebagai berikut:

$$
\eta_{i, j}^{(n)}=\zeta^{(n)}+\alpha_{i}^{(n)}+\delta_{j}^{(n)} ; n \in\{1,2, \ldots, N\}
$$


dengan $\zeta^{(n)}$ adalah intercept $\operatorname{dan} \alpha_{i}^{(n)}=\delta_{j}^{(n)}=0$.

Persamaan (11) akan digunakan untuk mengestimasi parameter. Oleh karena itu, berdasarkan konsep GLM dapat dibentuk parameter dari model GLM sebagai berikut:

$$
\boldsymbol{\beta}_{(I+J-1) \times 1}^{(n)}=\left(\zeta^{(n)}, \alpha_{2}^{(n)}, \ldots, \alpha_{I}^{(n)}, \delta_{2}^{(n)}, \ldots, \delta_{J}^{(n)}\right)^{T}
$$

\subsection{Regresi Copula}

Setelah nilai parameter dari GLM pada masing-masing line of business diketahui, selanjutnya diasumsikan bahwa antar line of business memiliki ketergantungan. Menurut Shi dan Frees (2011), untuk mengestimasi struktur dependensi antar line of business digunakan model regresi copula. Model GLM terbaik dari masing-masing line of business yang terpilih selanjutnya akan digunakan sebagai marginal dalam distribusi gabungan.

Berdasarkan Teorema Sklar, Fungsi distribusi gabungan dari besar pembayaran klaim incremental yang terstandarisasi $\left(X_{i, j}^{(1)}, \ldots, X_{i, j}^{(N)}\right)$ dapat ditulis sebagai berikut:

$$
F_{i, j}\left(x_{i, j}^{(1)}, \ldots, x_{i, j}^{(N)}\right)=P\left\{X_{i, j}^{(1)} \leq x_{i, j}^{(1)}, \ldots, X_{i, j}^{(N)} \leq x_{i, j}^{(n N)}\right\}=C\left(F_{i, j}^{(1)}\left(x_{i, j}^{(1)}\right), \ldots, F_{i, j}^{(N)}\left(x_{i, j}^{(N)}\right)\right)
$$

dengan $F_{i, j}^{(1)}, \ldots, F_{i, j}^{(N)}$ merupakan fungsi distribusi marginal dari besar pembayaran klaim incremental yang terstandarisasi $\left(X_{i, j}^{(1)}, \ldots, X_{i, j}^{(N)}\right)$.

Misalkan $\eta_{i, j}^{(n)}$ dan $\gamma^{(n)}$ dengan $n \in\{1,2, \ldots, N\}$, merupakan parameter yang tidak diketahui yang akan diestimasi untuk segitiga run-off masing-masing line of business, dan $\boldsymbol{\theta}$ merupakan vektor parameter dari fungsi copula. Sehingga vektor parameter dari model regresi copula yang akan diestimasi dapat dinotasikan $\boldsymbol{\phi}$, dengan $\boldsymbol{\phi}=$ $\left(\boldsymbol{\beta}^{(1)}, \ldots, \boldsymbol{\beta}^{(N)}, \gamma^{(1)}, \ldots, \gamma^{(N)} ; \boldsymbol{\theta}\right)^{T}$.

Untuk mengestimasi parameter dari model akan digunakan metode maksimum likelihood. Fungsi densitas dari distribusi gabungan untuk pembayaran klaim incremental yang terstandarisasi dengan diketahui fungsi copula seperti dalam Persamaan (12), dapat ditulis sebagai berikut:

$$
f_{i, j}\left(x_{i, j}^{(1)}, \ldots, x_{i, j}^{(N)}\right)=c\left(F_{i, j}^{(1)}\left(x_{i, j}^{(1)}\right), \ldots, F_{i, j}^{(N)}\left(x_{i, j}^{(N)}\right) ; \boldsymbol{\theta}\right) \prod_{n=1}^{N} f_{i, j}^{(n)}
$$

dengan $f_{i, j}^{(n)}$ dinotasikan sebagai fungsi densitas dari distribusi marginal $F_{i, j}^{(n)}$, sehingga dapat ditulis $f_{i, j}^{(n)}=f^{(n)}\left(x_{i, j}^{(n)}, \eta_{i, j}^{(n)} ; \gamma^{(n)}\right)$ untuk $n \in\{1,2, \ldots, N\}$.

Setelah fungsi distribusi gabungan ditentukan, maka fungsi likelihood dan fungsi log likelihood untuk $x_{i, j}^{(1)}, \ldots, x_{i, j}^{(N)}$ dari sampel random $X_{i, j}^{(1)}, \ldots, X_{i, j}^{(N)}$ dengan $(i, j) \in\{(i, j) ; i+$ $j \leq I\}$ dapat didefinisikan sebagai berikut:

$$
L\left(\phi ; x_{i, j}^{(n)}\right)=\sum_{i=1}^{I} \sum_{j=1}^{I-i} c\left(F_{i, j}^{(1)}\left(x_{i, j}^{(1)}\right), \ldots, F_{i, j}^{(N)}\left(x_{i, j}^{(N)}\right) ; \boldsymbol{\theta}\right) \prod_{n=1}^{N} f_{i, j}^{(n)}
$$

dan

$$
\ell\left(\phi ; x_{i, j}^{(n)}\right)=\sum_{i=1}^{I} \sum_{j=1}^{I-i} \log c\left(F_{i, j}^{(1)}\left(x_{i, j}^{(1)}\right), \ldots, F_{i, j}^{(N)}\left(x_{i, j}^{(N)}\right) ; \boldsymbol{\theta}\right)+\sum_{i=1}^{I} \sum_{j=1}^{I=i} \sum_{n=1}^{N} \log f_{i, j}^{(n)}
$$

Dengan demikian, estimator dari metode maksimum likelihood $\hat{\phi}$ dapat diperoleh sebagai berikut:

$$
\widehat{\boldsymbol{\phi}}=\arg \max _{\boldsymbol{\phi}}\left(\boldsymbol{\phi}, x_{i, j}^{(n)}\right)
$$

\section{METODE PENELITIAN}

Data yang digunakan untuk mengestimasi cadangan klaim menggunakan GLM dan Copula adalah data klaim asuransi tanggung gugat yang ditampilkan dalam bentuk segitiga 
run-off agregat incremental yang terstandarisasi untuk perseorangan, perusahaan dan profesional. Data besar pembayaran klaim asuransi tanggung gugat untuk periode Januari 2011 sampai dengan Desember 2011 dari masing-masing line of business yang disajikan dalam bentuk segitiga run-off agregat incremental terstandarisasi.

Berikut adalah langkah-langkah untuk mengestimasi cadangan klaim beberapa line of business menggunakan GLM dan Copula:

1. Data yang akan digunakan jenis data asuransi tanggung gugat dan disajikan dalam bentuk segitiga run-off agregat incremental.

2. Dinotasikan $X_{i, j}^{(n)}$, merupakan besar pembayaran klaim incremental yang terstandarisasi pada line of business ke- $n$.

3. Menentukan distribusi untuk data pada masing-masing line of business.

4. Menetapkan model marginal yang sesuai. Disini besar pembayaran klaim menggunakan GLM gamma untuk masing-masing line of business. Mengestimasi parameter model marginal (GLM) menggunakan MLE.

5. Mengestimasi parameter copula pada regresi copula dengan asumsi sebagai berikut

a. Estimator dari mean dinotasikan $\hat{\mu}_{i, j}^{(n)}$ dan estimator parameter dispersi dinotasikan $\hat{\gamma}^{(n)}$, masing-masing diperoleh dari hasil estimasi parameter model GLM terpilih.

b. Fungsi distribusi yang akan diestimasi yaitu $F_{i, j}^{(n)}$.

c. Diasumsikan $u_{i, j}^{(n)}$ berdistribusi uniform, diperoleh dengan menyatakan nilai fungsi distribusi $F_{i, j}^{(n)}$ dari besar pembayaran klaim incremental yang terstandarisasi, yaitu:

$$
u_{i, j}^{(n)}=F_{i, j}^{(n)}\left(x_{i, j}^{(n)}\right) \text {. }
$$

d. Parameter dari copula $\boldsymbol{\theta}$ diestimasi menggunakan metode maksimum likelihood dengan memaksimumkan fungsi densitas copula $c\left(u_{i, j}^{(1)}, u_{i, j}^{(2)}, \ldots, u_{i, j}^{(N)} ; \boldsymbol{\theta}\right)$.

Langkah-langkah regresi copula dilakukan untuk kelas copula Archimedean yaitu copula Clayton dan Gumbel. Untuk pemilihan copula terbaik akan digunakan AIC.

6. Setelah terpilih copula terbaik, maka dapat dilakukan estimasi cadangan klaim dengan langkah-langkah sebagai berikut:

i. Notasi $\left(u_{i, j}^{(1)}, u_{i, j}^{(2)}, \ldots, u_{i, j}^{(N)}\right)$ dibangun berdasarkan copula terpilih untuk periode kejadian $i$ dan periode perkembangan $j$ dengan $i+j>I$.

ii. Notasi $x_{i, j}^{(n)}$ adalah besar pembayaran klaim incremental terstandarisasi yang disimulasikan sebagai fungsi invers dari $F_{i, j}^{(n)}$, maka dapat ditulis:

$x_{i, j}^{(n)}=\left(F_{i, j}^{(n)}\right)^{(-1)}\left(u_{i, j}^{(n)}\right)$.

Proses simulasi diulang sebanyak $B$ kali, kemudian hasil dari simulasi digunakan untuk mengestimasi cadangan klaim.

iii. Besar klaim yang belum dibayarkan dapat dinotasikan dengan:

$$
\sum_{n=1}^{N} \sum_{j=I-i+2}^{J} x_{i, j}^{(n)} \omega_{i}^{(n)}
$$




\section{HASIL DAN PEMBAHASAN}

\subsection{Es timasi Parameter GLM}

Tahap awal dari metode GLM adalah mengestimasi parameter variabel independen, yaitu variabel periode kejadian dan variabel periode perkembangan. Sebelumnya terlebih dahulu dilakukan uji korelasi untuk melihat apakah ada depedensi antara perseorangan, perusahaan dan profesional. Hasil korelasi ketiganya adalah terdapat depedensi antara perseorangan dan perusahaan yaitu 0,94206, antara perusahaan dan profesional yaitu 0,94539 serta antara perorangan dan profesional yaitu 0,96071. Selanjutnya mengestimasi parameter variabel periode kejadian dan variabel periode perkembangan dengan memodelkan data dari masing-masing line of business menggunakan GLM gamma. Dengan menggunakan program $R$, diperoleh hasil estimasi parameter dari masing-masing line of business seperti terlihat pada Tabel 1.

Tabel 1. Hasil Estimasi Parameter GLM

\begin{tabular}{cccccccc}
\hline & Perorangan & Perusahaan & Profesional & & Perorangan & Perusahaan & Profesional \\
\hline$\zeta$ & 5,27633 & 5,32227 & 5,24882 & & & & \\
$\alpha_{2}$ & $-0,09133$ & $-0,04036$ & 0,03418 & $\delta_{2}$ & $-0,18847$ & $-0,18631$ & $-0,15488$ \\
$\alpha_{3}$ & 0,00200 & 0,03183 & 0,01182 & $\delta_{3}$ & $-0,24878$ & $-0,22359$ & $-0,19776$ \\
$\alpha_{4}$ & 0,02412 & 0,04670 & 0,03543 & $\delta_{4}$ & $-0,22127$ & $-0,27526$ & $-0,20009$ \\
$\alpha_{5}$ & 0,03831 & 0,04775 & 0,07947 & $\delta_{5}$ & $-0,57054$ & $-0,59520$ & $-0,52942$ \\
$\alpha_{6}$ & 0,16595 & 0,13320 & 0,14071 & $\delta_{6}$ & $-0,87076$ & $-0,91747$ & $-0,84188$ \\
$\alpha_{7}$ & 0,23862 & 0,20845 & 0,23681 & $\delta_{7}$ & $-1,18924$ & $-1,22901$ & $-1,17065$ \\
$\alpha_{8}$ & 0,40326 & 0,34757 & 0,38969 & $\delta_{8}$ & $-1,55218$ & $-1,61694$ & $-1,55703$ \\
$\alpha_{9}$ & 0,54251 & 0,57417 & 0,61655 & $\delta_{9}$ & $-2,04997$ & $-2,13190$ & $-2,04757$ \\
$\alpha_{10}$ & 0,94889 & 0,95340 & 0,92782 & $\delta_{10}$ & $-2,92843$ & $-2,94837$ & $-2,86648$ \\
$\alpha_{11}$ & 1,32797 & 1,36281 & 1,38368 & $\delta_{11}$ & $-3,57904$ & $-3,65057$ & $-3,60522$ \\
$\alpha_{12}$ & 2,14928 & 2,04218 & 2,11887 & $\delta_{12}$ & $-4,70063$ & $-4,79391$ & $-4,60738$ \\
\hline
\end{tabular}

Setelah diperoleh nilai parameter untuk masing-masing line of business, maka data dari masing-masing line of business perorangan, perusahaan dan profesional yang telah dimodelkan menggunakan GLM gamma digunakan sebagai model marginal copula.

\subsection{Estimasi Parameter Copula}

Tahap awal dalam memodelkan copula yaitu fungsi distribusi marginal dari masing-masing line of business dimodelkan menggunakan GLM gamma. Berdasarkan hasil estimasi parameter GLM pada Tabel 1 diperoleh parameter $\widehat{\boldsymbol{\beta}}^{(n)}$ dan $\widehat{\boldsymbol{\gamma}}^{(n)}$, dengan $\widehat{\boldsymbol{\beta}}^{(n)}=\left(\zeta^{(n)}, \alpha_{2}^{(n)}, \ldots, \alpha_{12}^{(n)}, \delta_{2}^{(n)}, \ldots, \delta_{12}^{(n)}\right)^{T}$ dan $\widehat{\boldsymbol{\gamma}}^{(n)}$ merupakan parameter dispersi untuk $n=1,2,3$. Tahap selanjutnya mengestimasi parameter model copula $\boldsymbol{\phi}=$ $\left(\widehat{\boldsymbol{\beta}}^{(1)}, \widehat{\boldsymbol{\beta}}^{(2)}, \widehat{\boldsymbol{\beta}}^{(3)}, \widehat{\boldsymbol{\gamma}}^{(1)}, \widehat{\boldsymbol{\gamma}}^{(2)}, \widehat{\boldsymbol{\gamma}}^{(3)}\right)$ menggunakan metode maksimum likelihood sesuai dengan Persamaan (16). Untuk memilih copula terbaik digunakan AIC, dimana hasil dengan nilai AIC terkecil yang dipilih sebagai model terbaik. Hasil estimasi parameter dari model copula disajikan pada Tabel 2. Berdasarkan tabel tersebut diperoleh bahwa copula Clayton merupakan model copula terbaik dengan nilai AIC lebih kecil dari nilai AIC copula Gumbel. Setelah terpilih model terbaik, maka tahap selanjutnya yaitu melakukan simulasi sebanyak 1000 kali dengan menggunakan copula Clayton berdasarkan GLM 
gamma untuk mencari estimasi cadangan klaim masing-masing line of business perorangan, perusahaan dan profesional.

Tabel 2. Hasil Estimasi Parameter Copula

\begin{tabular}{|c|c|c|c|c|c|c|}
\hline \multirow[b]{2}{*}{ Estimator } & \multicolumn{3}{|c|}{ Copula Clayton } & \multicolumn{3}{|c|}{ Copula Gumbel } \\
\hline & Perorangan & Perusahaan & Profesional & Perorangan & $\begin{array}{c}\text { Perusaha } \\
\text { an }\end{array}$ & Profesional \\
\hline$\zeta$ & 5,27639 & 5,31288 & 5,23846 & 5,27638 & 5,31301 & 5,23846 \\
\hline$\alpha_{2}$ & $-0,09138$ & $-0,04359$ & 0,03385 & $-0,09143$ & $-0,04390$ & 0,03385 \\
\hline$\alpha_{3}$ & 0,00186 & 0,03009 & 0,01077 & 0,00191 & 0,02979 & 0,01077 \\
\hline$\alpha_{4}$ & 0,02444 & 0,04529 & 0,03616 & 0,02398 & 0,04530 & 0,03617 \\
\hline$\alpha_{5}$ & 0,03818 & 0,04635 & 0,07909 & 0,03833 & 0,04631 & 0,07909 \\
\hline$\alpha_{6}$ & 0,16569 & 0,13218 & 0,14082 & 0,16608 & 0,13201 & 0,14082 \\
\hline$\alpha_{7}$ & 0,23859 & 0,20707 & 0,23736 & 0,23872 & 0,20685 & 0,23736 \\
\hline$\alpha_{8}$ & 0,40329 & 0,34664 & 0,39025 & 0,40341 & 0,34642 & 0,39025 \\
\hline$\alpha_{9}$ & 0,54264 & 0,57198 & 0,61517 & 0,54261 & 0,57168 & 0,61517 \\
\hline$\alpha_{10}$ & 0,94889 & 0,95159 & 0,92860 & 0,94897 & 0,95276 & 0,92861 \\
\hline$\alpha_{11}$ & 1,32795 & 1,36180 & 1,38453 & 1,32768 & 1,36189 & 1,38453 \\
\hline$\alpha_{12}$ & 2,14927 & 2,04216 & 2,12033 & 2,14923 & 2,04223 & 2,12034 \\
\hline$\delta_{2}$ & $-0,18870$ & $-0,18540$ & $-0,15437$ & $-0,18852$ & $-0,18560$ & $-0,15438$ \\
\hline$\delta_{3}$ & $-0,24863$ & $-0,22286$ & $-0,19688$ & $-0,24882$ & $-0,22307$ & $-0,19688$ \\
\hline$\delta_{4}$ & $-0,22096$ & $-0,27495$ & $-0,19963$ & $-0,22142$ & $-0,27482$ & $-0,19963$ \\
\hline$\delta_{5}$ & $-0,57062$ & $-0,59494$ & $-0,52840$ & $-0,57058$ & $-0,59485$ & $-0,52840$ \\
\hline$\delta_{6}$ & $-0,87113$ & $-0,91625$ & $-0,84051$ & $-0,87074$ & $-0,91636$ & $-0,84051$ \\
\hline$\delta_{7}$ & $-1,18925$ & $-1,22880$ & $-1,16996$ & $-1,18907$ & $-1,22872$ & $-1,16996$ \\
\hline$\delta_{8}$ & $-1,55217$ & $-1,61609$ & $-1,55854$ & $-1,55201$ & $-1,61613$ & $-1,55853$ \\
\hline$\delta_{9}$ & $-2,04981$ & $-2,13408$ & $-2,04817$ & $-2,04980$ & $-2,13420$ & $-2,04817$ \\
\hline$\delta_{10}$ & $-2,92844$ & $-2,94763$ & $-2,86602$ & $-2,92819$ & $-2,94766$ & $-2,86601$ \\
\hline$\delta_{11}$ & $-3,57903$ & $-3,65112$ & $-3,60379$ & $-3,57937$ & $-3,65104$ & $-3,60379$ \\
\hline$\delta_{12}$ & $-4,70064$ & $-4,79392$ & $-4,60592$ & $-4,70068$ & $-4,79386$ & $-4,60591$ \\
\hline$\gamma$ & 0,99424 & 0,51793 & 0,00031 & 0,99424 & 0,51793 & 0,00031 \\
\hline 1,2 & & 0,0001 & & & 1,000119 & \\
\hline 1,3 & & 0,0001 & & & 1 & \\
\hline 2,3 & & 0,0001438081 & & & 1 & \\
\hline LL & & $-664,439$ & & & $-664,436$ & \\
\hline AIC & & $-1230,878$ & & & $-1230,872$ & \\
\hline
\end{tabular}

Hasil estimasi cadangan klaim per periode kejadian untuk masing-masing line of business perorangan, perusahaan dan profesional dengan menggunakan GLM dan copula disajikan dalam Tabel 3, 4 dan 5, dimana estimasi cadangan klaimnya terletak pada segitiga bawah pada masing-masing tabel. 
Tabel 3. Estimasi Cadangan Klaim Per Periode Kejadian Klaim Menggunakan GLMCopula Untuk Line of Business Perorangan (dalam ribuan)

\begin{tabular}{|c|c|c|c|c|c|c|c|c|c|c|c|c|c|}
\hline \multirow{2}{*}{$\begin{array}{l}\text { Periode } \\
\text { Kejadian }\end{array}$} & \multicolumn{12}{|c|}{ Periode Perkembangan } & \multirow{2}{*}{$\begin{array}{l}\text { Total per } \\
\text { Periode } \\
\text { Kejadian } \\
\end{array}$} \\
\hline & 1 & 2 & 3 & 4 & 5 & 6 & 7 & 8 & 9 & 10 & 11 & 12 & \\
\hline 201101 & 3301 & 2570 & 2438 & 2599 & 1849 & 1351 & 1005 & 720 & 446 & 191 & 95 & 30 & \\
\hline 201102 & 3143 & 2510 & 2213 & 2299 & 1586 & 1136 & 811 & 553 & 345 & 151 & 76 & 26 & 26 \\
\hline 201103 & 3180 & 2649 & 2531 & 2554 & 1804 & 1323 & 1007 & 677 & 428 & 157 & 90 & 29 & 120 \\
\hline 201104 & 3126 & 2673 & 2509 & 2687 & 1915 & 1424 & 1023 & 692 & 404 & 176 & 94 & 30 & 299 \\
\hline 201105 & 2997 & 2598 & 2486 & 2500 & 1758 & 1385 & 971 & 702 & 400 & 160 & 86 & 28 & 674 \\
\hline 201106 & 3270 & 2704 & 2663 & 2695 & 1928 & 1350 & 997 & 711 & 421 & 186 & 91 & 30 & 1439 \\
\hline 201107 & 3134 & 2614 & 2528 & 2571 & 1801 & 1358 & 1000 & 676 & 403 & 172 & 92 & 28 & 2371 \\
\hline 201108 & 3208 & 2808 & 2526 & 2475 & 1763 & 1314 & 991 & 664 & 413 & 169 & 92 & 29 & 3672 \\
\hline 201109 & 3008 & 2421 & 2289 & 2413 & 1679 & 1253 & 918 & 655 & 387 & 162 & 79 & 27 & 5160 \\
\hline 201110 & 3184 & 2698 & 2503 & 2481 & 1893 & 1355 & 968 & 681 & 431 & 177 & 91 & 29 & 8106 \\
\hline 201111 & 2932 & 2339 & 2287 & 2304 & 1643 & 1195 & 861 & 623 & 383 & 151 & 81 & 26 & 9553 \\
\hline 201112 & 3325 & 2758 & 2561 & 2638 & 1853 & 1359 & 1006 & 728 & 427 & 182 & 94 & 31 & 13638 \\
\hline & & & & & Tot & & & & & & & & 45057 \\
\hline
\end{tabular}

Tabel 3 menunjukkan bahwa perusahaan asuransi harus menyiapkan dana cadangan pada bulan Januari 2012 (periode perkembangan ke-12) untuk menyelesaikan klaim yang terjadi pada bulan Februari 2012 (periode kejadian ke-2) sebesar 26. Kemudian perusahaan asuransi harus menyiapkan dana cadangan pada bulan Januari 2012 (periode perkembangan ke-11) sebesar 90 dan pada bulan Februari 2012 (periode perkembangan ke-12) sebesar 29 untuk menyelesaikan klaim yang terjadi pada bulan Maret 2012 (periode kejadian ke-3), dan seterusnya. Sehingga diperoleh total hasil estimasi cadangan klaim asuransi tanggung gugat untuk line of business perorangan menggunakan GLM dan copula sebesar 45.057.

Tabel 4. Estimasi Cadangan Klaim Per Periode Kejadian Klaim Menggunakan GLMCopula Untuk Line of Business Perusahaan (dalam ribuan)

\begin{tabular}{|c|c|c|c|c|c|c|c|c|c|c|c|c|c|}
\hline \multirow{2}{*}{$\begin{array}{c}\text { Periode } \\
\text { Kejadian }\end{array}$} & \multicolumn{12}{|c|}{ Periode Perkembangan } & \multirow{2}{*}{$\begin{array}{l}\text { Total per } \\
\text { Periode } \\
\text { Kejadian }\end{array}$} \\
\hline & 1 & 2 & 3 & 4 & 5 & 6 & 7 & 8 & 9 & 10 & 11 & 12 & \\
\hline 201101 & 3190 & 2821 & 2725 & 2771 & 2023 & 1376 & 1000 & 689 & 396 & 180 & 94 & 29 & \\
\hline 201102 & 3071 & 2653 & 2654 & 2397 & 1783 & 1310 & 985 & 663 & 391 & 163 & 80 & 26 & 26 \\
\hline 201103 & 3443 & 2820 & 2613 & 2531 & 1777 & 1349 & 970 & 666 & 435 & 185 & 89 & 28 & 117 \\
\hline 201104 & 3457 & 2923 & 2693 & 2649 & 1887 & 1372 & 969 & 673 & 374 & 173 & 88 & 28 & 289 \\
\hline 201105 & 3412 & 2767 & 2566 & 2542 & 1832 & 1312 & 936 & 633 & 381 & 168 & 85 & 27 & 660 \\
\hline 201106 & 3401 & 2767 & 2685 & 2628 & 1881 & 1381 & 1042 & 669 & 407 & 173 & 88 & 29 & 1366 \\
\hline 201107 & 3491 & 2812 & 2764 & 2541 & 1790 & 1307 & 976 & 654 & 401 & 179 & 85 & 27 & 2323 \\
\hline 201108 & 3174 & 2801 & 2585 & 2480 & 1812 & 1316 & 945 & 648 & 382 & 170 & 86 & 27 & 3573 \\
\hline 201109 & 3553 & 2887 & 2769 & 2424 & 1850 & 1376 & 997 & 670 & 408 & 181 & 88 & 27 & 5596 \\
\hline 201110 & 3390 & 2738 & 2855 & 2632 & 1826 & 1349 & 971 & 680 & 400 & 178 & 88 & 28 & 8153 \\
\hline 201111 & 3479 & 2765 & 2661 & 2571 & 1864 & 1339 & 1000 & 668 & 404 & 178 & 89 & 28 & 10802 \\
\hline 201112 & 3175 & 2658 & 2476 & 2410 & 1742 & 1263 & 934 & 619 & 368 & 168 & 83 & 26 & 12747 \\
\hline \multicolumn{13}{|c|}{ Total } & 45652 \\
\hline
\end{tabular}


Tabel 5. Estimasi Cadangan Klaim Per Periode Kejadian Klaim Menggunakan GLMCopula Untuk Line of Business Profesional (dalam ribuan)

\begin{tabular}{|c|c|c|c|c|c|c|c|c|c|c|c|c|c|}
\hline \multirow{2}{*}{$\begin{array}{c}\text { Periode } \\
\text { Kejadian }\end{array}$} & \multicolumn{12}{|c|}{ Periode Perkembangan } & \multirow{2}{*}{$\begin{array}{c}\text { Total per } \\
\text { Periode } \\
\text { Kejadian }\end{array}$} \\
\hline & 1 & 2 & 3 & 4 & 5 & 6 & 7 & 8 & 9 & 10 & 11 & 12 & \\
\hline 201101 & 9240 & 7972 & 7722 & 7703 & 5610 & 4088 & 3012 & 2067 & 1257 & 528 & 260 & 95 & \\
\hline 201102 & 10019 & 8533 & 8076 & 8073 & 5782 & 4241 & 3072 & 2077 & 1300 & 574 & 268 & 98 & 98 \\
\hline 201103 & 9373 & 8086 & 7861 & 7904 & 5589 & 3995 & 2824 & 1901 & 1173 & 535 & 251 & 92 & 344 \\
\hline 201104 & 9574 & 8185 & 7741 & 7816 & 5605 & 4121 & 2939 & 1961 & 1206 & 534 & 255 & 94 & 884 \\
\hline 201105 & 9405 & 8383 & 7888 & 7679 & 5613 & 4163 & 3002 & 2080 & 1227 & 541 & 259 & 95 & 212 \\
\hline 201106 & 9413 & 8370 & 7881 & 7826 & 5563 & 4120 & 2960 & 1990 & 1220 & 538 & 258 & 95 & 4100 \\
\hline 201107 & 9410 & 8039 & 7645 & 7791 & 5555 & 4069 & 2895 & 1963 & 1203 & 531 & 254 & 93 & 6939 \\
\hline 201108 & 9677 & 8125 & 7957 & 7877 & 5714 & 4117 & 2965 & 2008 & 1231 & 543 & 260 & 95 & 11219 \\
\hline 201109 & 9982 & 8106 & 7797 & 7795 & 5604 & 4100 & 2952 & 2001 & 1226 & 541 & 259 & 95 & 16777 \\
\hline 201110 & 9462 & 8175 & 7896 & 7745 & 5576 & 4080 & 2935 & 1989 & 1219 & 538 & 257 & 94 & 24433 \\
\hline 201111 & 9493 & 7999 & 7662 & 7635 & 5499 & 4025 & 2895 & 1964 & 1203 & 531 & 254 & 93 & 31761 \\
\hline 201112 & 9545 & 8105 & 7767 & 7748 & 5577 & 4083 & 2937 & 1991 & 1220 & 538 & 257 & 94 & 40318 \\
\hline \multicolumn{13}{|c|}{ Total } & 138996 \\
\hline
\end{tabular}

Dari Tabel 4 terlihat bahwa perusahaan asuransi harus menyiapkan dana cadangan pada bulan Januari 2012 untuk menyelesaikan klaim yang terjadi pada bulan Februari 2012 sebesar 26. Kemudian perusahaan asuransi harus menyiapkan dana cadangan pada bulan Januari 2012 sebesar 89 dan pada bulan Februari 2012 sebesar 28 untuk menyelesaikan klaim yang terjadi pada bulan Maret 2012, dan seterusnya. Sehingga diperoleh total hasil estimasi cadangan klaim asuransi tanggung gugat untuk line of business perusahaan menggunakan GLM dan copula sebesar 45.652.

Table 6. Perbedaan Estimasi Cadangan Klaim Menggunakan GLM dan GLM-Copula

\begin{tabular}{crrrrrr}
\hline Periode & \multicolumn{3}{c}{ GLM-Copula } & & \multicolumn{3}{c}{ GLM } \\
\cline { 2 - 6 } Kejadian & Perorangan & Perusahaan & Profesional & Perorangan & Perusahaan & Profesional \\
\hline 201102 & 25.790 & 25.985 & 98.132 & 25.544 & 26.682 & 98.992 \\
201103 & 119.515 & 117.298 & 343.743 & 118.091 & 116.134 & 347.150 \\
201104 & 299.018 & 289.332 & 883.644 & 296.314 & 294.264 & 891.689 \\
201105 & 674.042 & 660.081 & 2.122 .227 & 694.929 & 674.806 & 2.145 .258 \\
201106 & 1.438 .454 & 1.365 .939 & 4.100 .406 & 1.429 .784 & 1.383 .428 & 4.146 .370 \\
201107 & 2.370 .626 & 2.322 .596 & 6.938 .814 & 2.349 .854 & 2.344 .559 & 7.006 .771 \\
201108 & 3.672 .277 & 3.572 .861 & 11.219 .432 & 3.703 .251 & 3.580 .024 & 11.322 .496 \\
201109 & 5.159 .578 & 5.596 .236 & 16.777 .347 & 5.105 .137 & 5.636 .783 & 16.963 .511 \\
201110 & 8.106 .005 & 8.153 .003 & 24.433 .350 & 8.109 .349 & 8.229 .972 & 24.645 .668 \\
201111 & 9.553 .526 & 10.801 .481 & 31.760 .873 & 9.500 .656 & 10.917 .059 & 32.044 .693 \\
201112 & 13.637 .903 & 12.747 .433 & 40.317 .947 & 13.727 .996 & 12.815 .800 & 40.658 .249 \\
\hline Total & 45.056 .733 & 45.652 .247 & 138.995 .915 & 45.060 .905 & 46.019 .512 & 140.270 .846 \\
\hline & & & & & &
\end{tabular}

Sedangkan pada Tabel 5 menunjukkan bahwa perusahaan asuransi harus menyiapkan dana cadangan pada bulan Januari 2012 untuk menyelesaikan klaim yang 
terjadi pada bulan Februari 2012 sebesar 98. Kemudian perusahaan asuransi harus menyiapkan dana cadangan pada bulan Januari 2012 sebesar 251 dan pada bulan Februari 2012 sebesar 92 untuk menyelesaikan klaim yang terjadi pada bulan Maret 2012 dan seterusnya. Sehingga diperoleh total hasil estimasi cadangan klaim asuransi tanggung gugat untuk line of business profesional menggunakan GLM dan copula sebesar 138.996.

Selanjutnya diberikan perbedaan estimasi cadangan klaim per periode kejadian menggunakan GLM dan GLM-Copula seperti terlihat pada Tabel 6. Tabel tersebut menunjukkan bahwa estimasi cadangan klaim menggunakan GLM-copula nilainya lebih kecil dibandingkan menggunakan GLM untuk semua line of business.

\section{KESIMPULAN}

Berdasarkan hasil dan pembahasan diperoleh kesimpulan bahwa terdapat korelasi antar line of business perorangan, perusahaan dan profesional menunjukkan bahwa ketiganya saling berhubungan sehingga model copula dapat digunakan untuk memodelkan dependensi antar line of business. Model marginal yang digunakan adalah model GLM gamma untuk masing-masing line of business. Model copula yang digunakan adalah copula Clayton sebagai copula terbaik.

\section{DAFTAR PUSTAKA}

England, P. D., and Verrall, R. J. 2002. Stochastic Claims Reserving in General Insurance. British Actuarial Journal, 102(8):443-544.

Mack, T., 1993. Distribution-free Calculation of the Standard Error of Chain Ladder Method Reserves Estimates. ASTIN Bulletin. Volume 23, 213-225.

McCullagh, P. dan Nelder, J.A. 1989. Generalized Linear Models 2nd Edition. London. Chapman and Hall.

Nelsen, R.B. 2006. An Introduction to Copulas 2nd Edition. New York. Springer Science and Business Media, Inc.

Pevšta, M. dan Okhrin, O. 2014. Conditional Least Squares and Copulae in Claims Reserving for a Single Line of Business. Journal of Insurance: Mathematics and Economics. Volume 56 (2014), 28-37.

Rahmah, M.A. 2019. Estimasi Cadangan Klaim Menggunakan Copula Berdasarkan Generalized Linear Model (GLM) untuk Multiple Line Of Business. Tesis. Universitas Gadjah Mada.

Shi, P. dan Frees, E. 2011. Dependent Loss Reserving using Copulas. ASTIN Bulletin. 41: 449-486.

Valentovičová, K. 2015. Claim Reserving With Copulae For Multiple Line of Business. Master Thesis. Charles University in Prague.

Wüthrich, M dan Merz, M. 2008. Stochastic Claims Reserving Methods in Insurance. Canada. John Wiley and Sons. 